\section{Regards sur l'économie allemande}

Bulletin économique du CIRAC

$95 \mid 2010$

Varia

\title{
Crise financière
}

ZIMMERMANN Klaus F., SCHÄFER Dorothea, Finanzmärkte nach dem Flächenbrand - Warum es dazu kam und was wir daraus lernen müssen

\section{OpenEdition}

\section{Journals}

Édition électronique

URL : http://journals.openedition.org/rea/4052

DOI : 10.4000/rea.4052

ISBN : 978-2-8218-0886-7

ISSN : 1965-0787

Éditeur

CIRAC

Édition imprimée

Date de publication : 1 mars 2010

ISSN : 1156-8992

Référence électronique

"Crise financière », Regards sur l'économie allemande [En ligne], 95 | mars 2010, mis en ligne le 08 mars 2010, consulté le 22 septembre 2020. URL : http://journals.openedition.org/rea/4052 ; DOI : https:// doi.org/10.4000/rea.4052

Ce document a été généré automatiquement le 22 septembre 2020

(C) CIRAC 


\section{Crise financière}

ZIMMERMANN Klaus F., SCHÄFER Dorothea, Finanzmärkte nach dem

Flächenbrand - Warum es dazu kam und was wir daraus lernen müssen

\section{RÉFÉRENCE}

ZIMMERMANN Klaus F., SCHÄFER Dorothea, Finanzmärkte nach dem Flächenbrand Warum es dazu kam und was wir daraus lernen müssen, Gabler, Wiesbaden, 2010, 260p.

1 Le président et la directrice de recherches sur les marchés financiers de l'institut de recherches économiques DIW (Berlin) reviennent ici sur les éléments déclencheurs et la gestion politique de la crise financière. Fidèles à la tradition d'expertise du DIW, ils émettent des recommandations sur la structuration du système bancaire allemand et la régulation des marchés financiers internationaux. Un manuel à vocation pédagogique. (sh) 